\title{
The Monthly Barometer Of The Indian Stock Market
}

\author{
Jayen B. Patel, Adelphi University, USA
}

\begin{abstract}
The January Barometer or the Other January effect suggests that January returns can predict future performance of the stock market. In this study, it is examined if any particular calendar month return can effectively be used as a monthly barometer to accurately predict future direction of the Indian stock market. The results indicate none of the calendar month returns has consistent ability to accurately predict the performance of the Indian stock market over the next twelve months. The accuracy of prediction did not substantially improve whether the predictor month had generated positive or negative returns. The results continue to remain remarkably consistent when the predictability accuracy was analyzed over time by examining the effect separately over years. The findings of this study clearly demonstrate that the Indian stock market does not possess a monthly barometer that can accurately predict future direction of the stock market.
\end{abstract}

Keywords: January Barometer; Indian Stock Market; Monthly Barometer; Other January Effect

\section{INTRODUCTION}

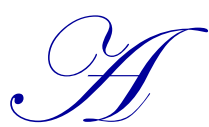

number of researchers have recently reported an intriguing phenomenon in stock returns that they refer as the January Barometer or the other January effect. According to this effect, the January returns are the barometer of the stock market and have the ability to predict returns of the remaining months of the year. More specifically, the other January effect suggests that when January returns are positive (negative), the rest of the year generates positive (negative) returns. The other January effect that has recently gained some popularity is distinctly different from the popular January effect that has been extensively investigated in stock markets. The January effect in stock returns indicates returns of January month are significantly higher than the mean returns of the remaining eleven months of the year. On the other hand, the other January effect claims that January return has the ability to accurately predict the direction of the stock market for the rest of the year. Researchers are unable to explain the existence of the other January effect in stock returns with any sound theoretical explanation. A thorough investigation is critical as persistence of this effect is clearly a violation of the well-accepted theory of market efficiency.

Many researchers argue that an effect, such as the other January effect, without any credible explanation can only be considered viable if it is examined during different time periods and in different financial markets. Researchers have examined this effect primarily in the U.S. stock market and in some international markets. The results are largely mixed whether January month can accurately predict the direction of the stock market for the rest of the year. Some researchers have also examined predictive ability of other calendar months with limited success in forecasting returns for the subsequent months of the year.

The other January effect needs to be examined in different financial markets and in a recent time period. This study attempts to fill this gap by investigating the other January effect in the Indian stock market, which is uniquely different from the U.S. stock market as well as other foreign markets. For example, Patel (2008) documents calendar effects detected in the Indian stock market are distinctively different from calendar regularities found in other stock markets around the world. Patel found that the Indian stock market does not exhibit the popular January effect prevalent in the U.S. stock market. He reports that the Indian stock market exhibits calendar effects where November and December generate higher returns than other months of the year. Alternately, March through May generate lower returns than other months of the year in the Indian stock market. Therefore, this research study 
considers the predictor month unconditional and does not impose a prior expectation on prediction ability on any particular calendar month for the Indian stock market. More specifically, this study investigates if any calendar month has predictive ability to forecast returns for the subsequent months.

\section{LITERATURE REVIEW}

Hensel and Ziemba (1995) examined the January Barometer phenomenon by examining the Standard and Poor's 500 index from 1926-1993. They concluded that January Barometer has good power in predicting the direction of the stock market for the subsequent eleven months. The predictive ability of January is particularly better when the January month generates a positive return in comparison to a negative return.

Cooper, McConnell and Ovtchinnikov (2006) examine the predictive power of January returns over the next eleven months for the period 1940-2003. The authors conclude that January returns have high predictive ability for the rest of the year. Cooper et al. state that when CRSP value-weighted index return is positive in January, the returns average 14.8 percent for the rest of the year. Alternately, when return of the value-weighted index is negative in January, the average return for the remainder of the year is 2.92 percent. Therefore, the spread, because of the other January effect, is almost 12 percent. When they examine the impact of the other January effect on the CRSP equally-weighted index, the spread is, in fact, much larger - almost 18 percent. Furthermore, the spreads continue to remain larger when they utilize excess returns and control for macroeconomic business cycles, presidential cycle in returns, and investment sentiment variables. The authors conclude that return from the month of January is a powerful precursor of average returns for the remaining months of the year for both large and small capitalization stocks as well as for value and growth stocks.

Easton and Pinder (2007) re-examined the existence of the other January effect in U.S. and thirty-eight other international equity markets for the period 1940-2003. The authors compared the results of their findings with that of Cooper et al. for the period 1973-2003. Easton and Pinder indicate that the predictive ability of January is largely confined to excess returns and not really prevalent for raw returns during the 1973-2003 period. Easton and Pinder state the importance of investigating the predictive ability of January returns with raw returns since this phenomenon has received attention because of market street-lore quotations that put emphasis on raw index returns. Furthermore, the authors add that when they examine the effect with excess returns, the predictive ability is not unique to the month of January. Easton and Pinder remark non-existence of the other January effect in other international equity markets, as well as in U.S. equity market, for the period 1973-2003 and cast serious doubt on the validity of this effect.

Brown and Luo (2006) examine the January Barometer for the period 1941-2003. The authors indicate that when the stock market generates high positive returns during the year, it is largely because of high returns generated in the month of January. Alternately, when stock market declines over a year, the return decreases relatively less in the month of January than other months of the year. Therefore, if investors want to invest in the stock market for only one month, they should invest in the month of January. The January Barometer succeeds when January is a down month because when January return is negative, the remaining eleven months also generate lower mean returns. On the other hand, the January Barometer fails when January returns generate positive returns because when January return is positive, the remaining eleven months continue to generate lower returns. In summary, Brown and Lou indicate that the January Barometer fails when it is a buy signal and succeeds when it a sell signal. The author states that January predictor month should also include return of subsequent January month in calculation of subsequent returns, like other calendar months, since January returns are higher in comparison to returns of all other months. When all twelve months are included as holding periods, it is found that January month has better predictive value compared to other months of the year.

Imhof and Brusa (2008) examine the predictive power of January returns in the U.S. and five other foreign equity markets. They state that the predictive power of January returns has been investigated in the U.S. equity market but unexplored in international equity markets. Therefore, they examine the predictive power of January returns in equity markets of Australia, Germany, Hong Kong, Japan and Switzerland. They found January returns have significant predictive ability in international equity markets as they have in the U.S. equity market. More specifically, they find that when January returns are positive in these five international markets, the returns are 
significantly positive for the year in these respective markets. Alternately, when January returns are negative, equity returns are not different from zero in these equity markets. Furthermore, they indicate that U.S. January returns have significant power in predicting returns of the five foreign equity markets that they examined in their study.

Brusa (2009) examined the other January effect in U.S. broad equity indices as well as thirty industry equity indices for the period 1940-2008. Brusa states that he wants to determine if the other January effect is concentrated in only some industries or if it is widely spread across several industries. Brusa finds that the effect exists in broad equity indices as well as several industry indices. However, it is found that the significance of this effect has diminished in some industries during later years of his sample. The effect has persisted in broad equity indices as well as in some industry indices. Brusa concludes that the other January effect is related to broad economic events which impact many sectors of the economy rather than some industry specific factor.

Sturm (2009) indicates that researchers have documented a relationship between January returns and those of the rest of the year. This relationship examined in previous literature - referred as the other January effect suggests that when January returns are positive (negative), the remaining eleven months generate positive (negative) returns in the stock market. Researchers have also documented that returns are higher during the second half over the first half of the U.S. presidential term. Sturm investigates whether the other January effect is affected by the presidential election cycle in the U.S. equity market for the period 1940-2006. Sturm finds that predictive power of January returns over the rest of the year is confined mostly to the first and fourth years of the presidential cycle. The author finds no evidence of predictive power of January returns over the rest of the year in second and third years of the presidential cycle.

Marshall and Visaltanachoti (2010) investigate whether the other January effect can be implemented by investors to earn risk-adjusted excess returns. If investors can earn abnormal returns using the other January effect, then it is evidence against market efficiency. Marshall and Visaltanachoti found that the other January effect underperformed a simple buy-and-hold strategy after, as well as before, adjustment of risk. They add that even the best modified strategy using the other January effect did not generate statistical and economical excess returns over a simple buy-and-hold investment strategy. Marshall and Visaltanachoti state that this effect is as profitable with January, as with November or December, as the conditioning month for the next eleven-month strategy. The author concludes that investors should be cautious in using the other January effect as a market timing tool as it does not provide any useful information. Finally, the other January effect does not provide any evidence against market efficiency.

The review of literature indicates that the so-called other January effect has received significant attention in academic research. Some researchers indicate that January has the ability to predict returns for subsequent months. Alternately, research results from other studies do not support the consistency of the other January effect. It appears that there is a need to examine this effect during different time periods and in different equity markets. This research study examines this effect in the Indian stock market using recent data as described in the next section.

\section{DATA}

The data for this study were collected from the National Stock Exchange of India (NSE). The NSE CNX 500 index is a broad-based market index that represents over 95 percent of market capitalization of the stocks listed on the exchange according to the NSE website. The NSE CNX 500 index consists of 500 company stocks which represent several sectors of the economy. The NSE website provides daily index values of the NSE CNX 500 index from June 7, 1999. For the purpose of this study, the index value of the last trading day of each month was collected from June 1999 to June 2012. The returns are calculated using the standard formula; therefore, this study has monthly returns from July 1999 to June 2012, resulting in 156 monthly return values for the analysis. The empirical results of this study are reported in the next section.

\section{EMPIRICAL FINDINGS}

This study initially reports the mean returns of the NSE CNX 500 index by each of the twelve months for the period July 1999 through June 2012. This study has a total of thirteen years of data; therefore, each monthly 
mean has thirteen observations. The results reported in Table 1 are consistent with earlier findings of Patel (2008) that November and December document high positive returns. More importantly, January returns are actually negative and lower that many other months of the year. Therefore, as indicated earlier, this research study does not focus on any single month, such as January, for predictive ability for the subsequent year, but rather investigates if any calendar month has the ability to predict future returns in the Indian market.

Table 1: Mean Monthly Percentage Returns of NSE CNX 500 Index July 1999 to June 2012

\begin{tabular}{|l|c|c|c|}
\hline \multicolumn{1}{|c|}{ Month } & Mean & Std. Deviation & Observations \\
\hline January & -0.50 & 8.60 & 13 \\
\hline February & 0.89 & 5.59 & 13 \\
\hline March & -1.64 & 9.15 & 13 \\
\hline April & 1.26 & 8.36 & 13 \\
\hline May & 0.44 & 13.90 & 13 \\
\hline June & 0.95 & 8.07 & 13 \\
\hline July & 2.19 & 6.97 & 13 \\
\hline August & 3.63 & 6.53 & 13 \\
\hline September & 0.83 & 8.90 & 13 \\
\hline October & -1.13 & 10.44 & 13 \\
\hline November & 4.40 & 6.94 & 13 \\
\hline December & 5.86 & 6.94 & $\mathbf{1 5 6}$ \\
\hline Average & $\mathbf{1 . 4 3}$ & $\mathbf{8 . 5 9}$ & \\
\hline
\end{tabular}

Next, this study analyzes mean returns of the subsequent twelve months for each predictor calendar month. It includes all twelve months as a subsequent holding period in the analysis. This research study believes months that generate relatively high returns (for example, November or December) or, alternately, lower returns (for example, March) should be included in determination of holding period returns of next year. The sample includes data from July 1999 to June 2012. Therefore, this study examines the predictive ability of July 1999 for the next twelve months, from August 1999 through July 2000. This study continues to investigate the ability of each month to predict returns for the next twelve months, up to June 2011, that examine the predictive ability from July 2011 through June 2012. Therefore, this research has a total of 144 subsequent annual return observations. Mean returns of the next twelve months (subsequent annual return) for each calendar predictor month are reported in Table 2.

Table 2: Mean Annual Percentage Returns of NSE CNX 500 Index: Next Twelve Months July 1999 to June 2012

\begin{tabular}{|c|c|c|c|c|}
\hline $\begin{array}{l}\text { Predictor } \\
\text { Month }\end{array}$ & $\begin{array}{l}\text { Annual Period } \\
\text { Next } 12 \text { Months }\end{array}$ & $\begin{array}{c}\text { Annual } \\
\text { Mean }\end{array}$ & Std. Deviation & Observations \\
\hline January & February to January & 17.63 & 44.03 & 12 \\
\hline February & March to February & 17.50 & 45.15 & 12 \\
\hline March & April to March & 18.34 & 46.83 & 12 \\
\hline April & May to April & 19.32 & 45.86 & 12 \\
\hline May & June to May & 14.81 & 25.00 & 12 \\
\hline June & July to June & 14.72 & 25.25 & 12 \\
\hline July & August to July & 16.58 & 24.28 & 12 \\
\hline August & September to August & 15.11 & 25.42 & 12 \\
\hline September & October to September & 16.65 & 32.66 & 12 \\
\hline October & November to October & 20.59 & 41.00 & 12 \\
\hline November & December to November & 19.89 & 44.08 & 12 \\
\hline December & January to December & 19.16 & 47.87 & 12 \\
\hline Average & & $\mathbf{1 7 . 5 3}$ & 37.01 & 144 \\
\hline
\end{tabular}

Note: The annual twelve-month holding returns are calculated for each month from July 1999 (August 1999 to July 2000$)$ to June 2011 (July 2011 to June 2012) resulting in 144 annual return observations.

The Indian stock market generated high positive long-term returns during the period July 1999 to June 2012. The annual twelve-month holding return subsequent to each month is remarkably high. The average of subsequent twelve-month returns during this period is 17.53 percent. The mean twelve-month return subsequent to 
June (July to next June) is relatively lower (14.72 percent) in comparison to other predictor months. The predictor month of October (November to next October) generated a relatively higher return (20.59 percent) in comparison to other prediction months. These results are not confounded with any calendar effect, such as the NovemberDecember effect or the March-to-May effect, documented earlier by Patel (2008) as this research study is using subsequent twelve months as holding period returns for detection of predictive ability of each calendar month.

This study now investigates the accuracy of predictive ability of each calendar month. This research considers prediction correct if the predictor month generates positive (negative) returns and the subsequent twelve months also generate positive (negative) returns. The prediction is considered incorrect if the predictor month generates positive (negative) returns and the subsequent twelve months move in the opposite direction and generates negative (positive) returns. The results are reported in Table 3.

Table 3: Prediction Accuracy of Calendar Month With Next Twelve Months July 1999 to June 2012

\begin{tabular}{|l|c|c|c|c|}
\hline \multicolumn{1}{|c|}{ Predictor Month } & Next 12 Months & Incorrect & Correct & Total \\
\hline January & February to January & $7(58.3 \%)$ & $5(41.7 \%)$ & 12 \\
\hline February & March to February & $8(66.7 \%)$ & $4(33.3 \%)$ & 12 \\
\hline March & April to March & $5(41.7 \%)$ & $7(58.3 \%)$ & 12 \\
\hline April & May to April & $4(33.3 \%)$ & $8(66.7 \%)$ & 12 \\
\hline May & June to May & $5(41.7 \%)$ & $7(58.3 \%)$ & 12 \\
\hline June & July to June & $7(58.3 \%)$ & $5(41.7 \%)$ & 12 \\
\hline July & August to July & $4(33.3 \%)$ & $8(66.7 \%)$ & 12 \\
\hline August & September to August & $3(25.0 \%)$ & $9(75.0 \%)$ & 12 \\
\hline September & October to September & $6(50.0 \%)$ & $6(50.0 \%)$ & 12 \\
\hline October & November to October & $5(41.7 \%)$ & $7(58.3 \%)$ & 12 \\
\hline November & December to November & $4(33.3 \%)$ & $8(66.7 \%)$ & 12 \\
\hline December & January to December & $4(33.3 \%)$ & $8(66.7 \%)$ & 12 \\
\hline Overall & & $\mathbf{6 2 ( 4 3 . 1 \% )}$ & $\mathbf{8 2 ( 5 6 . 9 \% )}$ & $\mathbf{1 4 4}$ \\
\hline
\end{tabular}

Note: The annual twelve-month holding returns are calculated for each month from July 1999 (August 1999 to July 2000 ) to June 2011 (July 2011 to June 2012) resulting in 144 annual return observations.

This study finds predictive accuracy of months between 33.3 percent (February) and 75.0 percent (August). The January month has a low predictive accuracy rate of merely 41.7 percent. Also, the November and December months, which have historically generated high positive returns in the Indian stock market, did not exhibit high predictive accuracy rates for the next twelve months. The overall prediction was correct 82 times out of a total of 144 predictor months which resulted in 56.9 percent correct predictions for the overall period. Furthermore, it is important to point out that none of the calendar months have distinctly superior or inferior ability to predict direction of the stock market for the next twelve months.

This study now investigates if the accuracy of prediction has changed over time. More specifically, this research is interested in determining the accuracy of predictive power by each calendar year. The results are reported in Table 4. The overall accuracy is 56.9 percent as reported in earlier analysis. The predictive accuracy of months by calendar year has a high degree of variation. The predictive accuracy is relatively high in some years, such as 2006 (83.3 percent), 2003 (75.0 percent), and 2004 (75.0 percent). On the other hand, the predictive accuracy is lower in later years, such as 2010 (33.3 percent), 2007 (41.7 percent), and 2008 (50.0 percent). These results indicate that the predictive ability of calendar months to forecast returns in the next twelve months is not consistent and accurate over time. 
Table 4: Prediction Accuracy by Calendar Year: Calendar Month With Next Twelve Months July 1999 to June 2012

\begin{tabular}{|l|c|c|c|}
\hline Year & Incorrect & Correct & Total \\
\hline 1999 & $3(50.0 \%)$ & $3(50.0 \%)$ & 6 \\
\hline 2000 & $5(41.7 \%)$ & $7(58.3 \%)$ & 12 \\
\hline 2001 & $9(75.0 \%)$ & $3(25.0 \%)$ & 12 \\
\hline 2002 & $5(41.7 \%)$ & $7(58.3 \%)$ & 12 \\
\hline 2003 & $3(25.0 \%)$ & $9(75.0 \%)$ & 12 \\
\hline 2004 & $3(25.0 \%)$ & $9(75.0 \%)$ & 12 \\
\hline 2005 & $4(33.3 \%)$ & $8(66.7 \%)$ & 12 \\
\hline 2006 & $2(16.7 \%)$ & $10(83.3 \%)$ & 12 \\
\hline 2007 & $7(58.3 \%)$ & $5(41.7 \%)$ & 12 \\
\hline 2008 & $6(50.0 \%)$ & $6(50.0 \%)$ & 12 \\
\hline 2009 & $4(33.3 \%)$ & $8(66.7 \%)$ & 12 \\
\hline 2010 & $8(66.7 \%)$ & $4(33.3 \%)$ & 12 \\
\hline 2011 & $3(50.0 \%)$ & $3(50.0 \%)$ & 6 \\
\hline Overall & $\mathbf{6 2 ( 4 3 . 1 \% )}$ & $\mathbf{8 2}(\mathbf{5 6 . 9 \%})$ & $\mathbf{1 4 4}$ \\
\hline
\end{tabular}

Note: The annual twelve-month holding returns are calculated for each month from July 1999 (August 1999 to July 2000) to June 2011 (July 2011 to June 2012) resulting in 144 annual return observations.

Next, this study investigates if predictive ability of calendar months is different when the return of the prediction month is positive or negative. The results are reported in Table 5. The data have 53 predictor months that generated negative returns and 91 predictor months that generated positive returns, for a total of 144 predictor months. Eighteen negative predictor months predicted correctly that the next twelve months will generate negative returns, which resulted in an accuracy rate of 34.0 percent for the 53 negative months. Alternately, 64 positive predictor months predicted correctly that the next twelve months will generate positive returns, which resulted in accuracy of 70.3 percent out of 91 months. The analysis shows that the accuracy is higher when it is a buy signal in comparison to a sell signal. This result may be partly because the Indian stock market has generated high positive returns during the thirteen years of this study. Therefore, it is more likely that the stock market will generate longterm positive returns.

Table 5: Accuracy of Prediction by Positive and Negative Monthly Returns July 1999 to June 2012

\begin{tabular}{|l|c|c|c|}
\hline \multicolumn{1}{|c|}{ Predictor Months } & Incorrect & Correct & Total \\
\hline Negative monthly returns & $35(66.0 \%)$ & $18(34.0 \%)$ & 53 \\
\hline Positive monthly returns & $27(29.7 \%)$ & $64(70.3 \%)$ & 91 \\
\hline Total & $\mathbf{6 2 ( 4 3 . 1 \% )}$ & $\mathbf{8 2}(\mathbf{5 6 . 9 \% )}$ & $\mathbf{1 4 4}$ \\
\hline
\end{tabular}

Note: The annual twelve-month holding returns are calculated for each month from July 1999 (August 1999 to July 2000$)$ to June 2011 (July 2011 to June 2012) resulting in 144 annual return observations.

Finally, this study reports the accuracy of each specific calendar month when it generated positive versus negative returns. This analysis determines if the accuracy is better for any particular month when it generates positive versus negative returns. The results are reported in Table 6 . The results of this analysis indicate that the prediction is relatively more accurate when the predictor month generates positive return in comparison to when the predictor month generates negative return. Interestingly, all the calendar months have better predictive power for a buy signal in comparison to a sell signal. However, it has to be reiterated that the overall accuracy rate for buy signal is only 70.3 percent as reported in earlier analysis. 
Table 6: Accuracy of Prediction by Each Months Positive and Negative Returns July 1999 to June 2012

\begin{tabular}{|c|c|c|c|c|c|}
\hline \\
\hline Month & Monthly Return & Next 12 Months & Incorrect & Correct & Total \\
\hline \multirow{2}{*}{ January } & Negative & February to January & $5(71.4 \%)$ & $2(28.6 \%)$ & 7 \\
\hline & Positive & February to January & $2(40.0 \%)$ & $3(60.0 \%)$ & 5 \\
\hline \multirow{2}{*}{ February } & Negative & March to February & $5(83.3 \%)$ & $1(16.7 \%)$ & 6 \\
\hline & Positive & March to February & $3(50.0 \%)$ & $3(50.0 \%)$ & 6 \\
\hline \multirow{2}{*}{ March } & Negative & April to March & $3(60.0 \%)$ & $2(40.0 \%)$ & 5 \\
\hline & Positive & April to March & $2(28.6 \%)$ & $5(71.4 \%)$ & 7 \\
\hline \multirow{2}{*}{ April } & Negative & May to April & $3(50.0 \%)$ & $3(50.0 \%)$ & 6 \\
\hline & Positive & May to April & $1(16.7 \%)$ & $5(83.3 \%)$ & 6 \\
\hline \multirow{2}{*}{ May } & Negative & June to May & $4(57.1 \%)$ & $3(42.9 \%)$ & 7 \\
\hline & Positive & June to May & $1(20.0 \%)$ & $4(80.0 \%)$ & 5 \\
\hline \multirow{2}{*}{ June } & Negative & July to June & $4(100.0 \%)$ & $0(0.0 \%)$ & 4 \\
\hline & Positive & July to June & $3(37.5 \%)$ & $5(62.5 \%)$ & 8 \\
\hline \multirow{2}{*}{ July } & Negative & August to July & $2(66.7 \%)$ & $1(33.3 \%)$ & 3 \\
\hline & Positive & August to July & $2(22.2 \%)$ & $7(77.8 \%)$ & 9 \\
\hline \multirow{2}{*}{ August } & Negative & September to August & $1(50.0 \%)$ & $1(50.0 \%)$ & 2 \\
\hline & Positive & September to August & $2(20.0 \%)$ & $8(80.0 \%)$ & 10 \\
\hline \multirow{2}{*}{ September } & Negative & October to September & $3(75.0 \%)$ & $1(25.0 \%)$ & 4 \\
\hline & Positive & October to September & $3(37.5 \%)$ & $5(62.5 \%)$ & 8 \\
\hline \multirow{2}{*}{ October } & Negative & November to October & $3(60.0 \%)$ & $2(40.0 \%)$ & 5 \\
\hline & Positive & November to October & $2(28.6 \%)$ & $5(71.4 \%)$ & 7 \\
\hline \multirow{2}{*}{ November } & Negative & December to November & $1(50.0 \%)$ & $1(50.0 \%)$ & 2 \\
\hline & Positive & December to November & $3(30.0 \%)$ & $7(70.0 \%)$ & 10 \\
\hline \multirow{2}{*}{ December } & Negative & January to December & $1(50.0 \%)$ & $1(50.0 \%)$ & 2 \\
\hline & Positive & January to December & $3(30.0 \%)$ & $7(70.0 \%)$ & 10 \\
\hline
\end{tabular}

\section{SUMMARY AND CONCLUSIONS}

The January Barometer - or the other January effect - suggests that January returns have ability to predict returns of the remaining year. This research study investigates if any particular calendar month has ability to predict returns for the next twelve months in the Indian stock market. The study examined this effect over each calendar predictor month as well as over time by calendar years. This study also investigated if the prediction improved when the predictor months were separated by positive and negative returns. The results clearly demonstrate that none of the calendar months can accurately predict returns of the subsequent twelve months consistently. This study concludes that these results are consistent with the efficient market theory as none of the calendar months could correctly predict future direction of the stock market.

\section{AUTHOR INFORMATION}

Jayen B. Patel is Professor of Finance in the Robert B. Willumstad School of Business at Adelphi University where he teaches corporate finance and investment classes. He earned his Doctor of Business Administration degree in finance from Mississippi State University. His work has been published in many journals including International Business and Economics Research Journal, Journal of Applied Business Research, Journal of Business and Economics Research and Journal of Financial Research. E-mail: ipatel@adelphi.edu

\section{REFERENCES}

1. Brown, L. D., \& Luo, L. (2006). The January barometer: Further evidence. The Journal of Investing, 15(1), 25-31.

2. Brusa, J. (2009). An industry analysis of the other January effect. Journal of International Finance and Economics, 8(4), 74-81.

3. Cooper, M. J., McConnell, J. J., \& Ovtchinnikov, A. V. (2006). The other January effect. Journal of Financial Economics, 82(2), 315-341. 
4. Easton, S. A., \& Pinder, S. M. (2007). A refutation of the existence of the other January effect. International Review of Finance, 7(3-4), 89-104.

5. Hensel \& Ziemba. (1995). The January Barometer. The Journal of Investing, 4(2), 67-70.

6. Imhof, M. J., \& Brusa, J. (2008). The other January effect: International evidence. International Journal of Business Research, 8(5), 48-52.

7. Marshall, B. R., \& Visaltanachoti, N. (2010). The other January effect: Evidence against market efficiency. Journal of Banking and Finance, 34(10), 2413-2424.

8. National Stock Exchange of India Website. Retrieved January 2013 from www.nseindia.com

9. Patel, J. B. (2008). Calendar effects in the Indian Stock Market. International Business and Economics Research Journal, 7(3), 61-69.

10. Sturm, R. R. (2009). The other January effect and the president election cycle. Applied Financial Economics, 19(17), 1355-1363. 